\title{
DO INVESTORS EXPERIENCE HEURISTICS IN EARNINGS FORECASTING?
}

\author{
Riza PRADITHA (1) ${ }^{*}$, Haliah HALIAH ${ }^{2}$, Abdul Hamid HABBE ${ }^{3}{ }^{3}$, Yohanis RURA ${ }^{4}$ \\ ${ }^{1}$ Accounting Deapartment, STIE Tri Dharma Nusantara, Makassar, Indonesia \\ 2, 3, 4 Accounting Department, Hasanuddin University, Makassar, Indonesia
}

Received 30 January 2020; accepted 4 May 2020

\begin{abstract}
This research aims to examine empirically the overreliance on representativeness heuristic and anchoring-adjustment influences experienced by investors in forecasting future earnings. This research was a laboratory experiment with a design of $2 \times 2$ full factorial between subject. The results showed that representativeness heuristics were only experienced by investors who obtained positive information. Besides, this study also shows that investors do not overreliance on anchoring-adjustment heuristics. Generally, this research shows that cognitive biases occur when the information presented is of good value so that it can be taken into consideration for investors to be more careful in making predictions. Multiple benchmark information can be used as a consideration in evaluating the company's earnings and stock performance.
\end{abstract}

Keywords: representativeness, anchoring-adjustment, multiple benchmark information.

JEL Classification: C91, G41, M41.

\section{Introduction}

The main goal in the discussion of earnings forecasting is not to find the best model but to identify useful models. In the context of capital market research and practical valuation, the most useful models are objective, replicable, accurate, and provide useful guidance (Monahan, 2017). Therefore, this research aims to provide a useful model for those who conduct earnings forecasting. Estimates of earnings are made by diverse populations such as analysts, independent investors, portfolio managers, as well as corporate finance and student (Jame et al., 2016). Estimated earnings are useful as a security valuation model (eg dividend) which is charged to future earnings. However, in the information that is projected to be higher, profits are more difficult to predict which will be lower (Konstantinidi \& Pope, 2016). This uncertainty depends on the quality of general, approved company information, and the timeliness of disclosing earnings information (Lim, 2001). These uncertain conditions allow for inaccuracies in forecasting future earnings. investors hate do be irrational, giving rise to what is known as capital market anomalies.

Anomalies that occur are a reflection of investor irrationality in making investment decisions. The irrationality of investors is a phenomenon of capital market inefficiency that starts from research (De Bondt \& Thaler, 1987). The research shows an overreaction to information so that investors tend to set prices too high due to good information (good news) and vice versa tend to set prices too low if they get new information that is considered bad (bad news). The irrational which later refuted Efficiency Market Hypothesis (Fama, 1970) who said that prices fully reflect all available information. This is related to the formation of a rational investor expectation where market prices combine all information rationally and instantaneously (Lo, 1989).

Psychologically, the irrationality of investors in the capital market can be due to the heuristic factors that investors have. Investors not only do mathematical calculations but also use instincts. Heuristics can be interpreted as "rule of thumb" which guides investors to act practically in making estimates. Heuristics will affect the estimated earnings made by investors and allow for bias in estimation. There are two general heuristics underlying investor decision making, namely representativeness and anchoring-adjustment heuristics (Tversky \& Kahneman, 1973). Representativeness explains the tendency of investors to make predictions of a company's future earnings based on similar past earnings. Heuristic representativeness is a psychological bias that explains that in conditions of uncertainty, an investor tends to believe in history in terms of the common results of a company's performance in general (Boussaidi, 2013).

*Corresponding author. E-mail: rizapradithaa@gmail.com 
Heuristic representativeness can bias decisions if they depend on information patterns. For example, the bias that occurs in a doctor's diagnosis of a patient's disease is influenced by pattern recognition which causes the doctor not to give enough appreciation so that the diagnosis tends to be the same (Richie \& Josephson, 2018). In the capital market, investors generally buy stocks after prices rise and expect this increase to continue. Conversely, investors tend to ignore stocks when the price is below its intrinsic value. Investors who use the heuristic representativeness in making investment decisions believe that they can see patterns that are actually random processes (Laih, 2016). However, investors with heuristic representativeness can get more expected benefits from misevaluations (made by noise traders) than rational investors (Ying Luo, 2013). As a result, the earnings expected by investors with heuristic representativeness are greater than rational investors. This can answer the question of why most investors use the heuristic representativeness in making estimates in the capital market.

In contrast to representational heuristics, anchor-adjustment heuristics describe individuals in making decisions related to anchors which are then replaced. An anchor is one of the deepest cognitive biases, and one hand is lacking on crystal balls that reveal the volatility of future results from all stocks, it's hard to see how anyone can run away from him. For typically stock, it forms an assessment of the volatility of future results forms judgments about something largely unknown. When faced with this task, the obvious thing to do is to start from what is known and make adjustments (Siddiqi, 2015). Anchoring-adjustment heuristics describe a phenomenon in which single information influences a decision, specific information found at a certain initial stage (Richie \& Josephson, 2018).

The behavioral finance theory explains that investors do not fully process data by really needing a wrong distribution solution to future earnings (Bodie et al., 2009). Pompian (2012) says that the anchor and adjustment bias occurs when a compilation of investors is required to estimate something that has not been recognized before. The investor will then set the default number or anchor as the basis for his estimated initiation. Past investors will adjust the estimated results slightly above or below the anchor value. The anchor-adjustment model explains the situation, the individual makes an estimate by departing from the initial value (anchor) which then talks (adjustments) with the results of the final answer (Tversky \& Kahneman, 1973; Gilovich \& Epley, 2006). Initial values can be offered in earnings for the past period (Wahyuni et al., 2016).

Both of heuristic factors, namely representativeness and anchoring-adjustment, cause cognitive biases that are considered as inaccuracies in predicting future earnings performance (Lee et al., 2016). Mistakes in predicting the company's future earnings will cause errors in predicting stock prices (mispriced). Therefore, this research examines empirically the overreliance on representativeness heuristic and anchoring-adjustment influences experienced by investors in forecasting future earnings. This research model has been previously conducted by Habbe (2017) and (Bloomfield et al., 2003). This research is different from Habbe (2017) and Bloomfield et al. (2003) in terms of output. That are focuses on investor behavior in predicting earnings rather than testing the level of stock price prediction errors.

In addition, this research is also different in terms of the use of information where this research uses a form of multiple benchmark information previously used by Wahyuni et al. (2016). However, this research uses the value of earning after tax as a benchmark while the research conducted by Wahyuni et al. (2016) use earning transitory. The different forms of information affect the treatment in the experimental method, so the instruments used in this research adjust to the form of multiple benchmark information by making earning after tax as a benchmark to see the possibility of differences in heuristic test results.

The inclusion of future information in disclosing the company's comparative information is called the Multiple Benchmark strategy. This strategy includes an explanation of the usefulness of mandatory and voluntary accounting information, internal and external information, past and future information, quantitative and qualitative information. Multiple benchmark strategy is an information disclosure strategy in earnings announcements made by companies that are based on more than one reference, namely past period earnings, current period earnings and future information. Future information can be in the form of Management Guidance. The management guide consists of internal information such as product and service issues and organizational issues, as well as external information in the form of economic conditions and government regulations (Wahyuni \& Hartono 2012; Wahyuni et al., 2016; Praditha et al., 2020). The use of information with multiple benchmark models illustrates that comprehensive disclosure of information can assist investors in predicting accounting information.

\section{Literature review}

\subsection{Multiple Refference Point Theory}

The theory of multiple reference points is one of the theories of psychology developed through the concept and practice of strategic reference points (SRP), better known as strategic benchmarks. In psychological research, benchmarks are referred to as comparison levels (Thibaut \& Kelley, 2017), adjustment levels (Helson, 1964), or reference points (Kahneman \& Tversky, 1979; Tversky, 1992). Fiegenbaum et al. (1996) explained that the strategic reference point is the company's choice in helping to achieve strategic alignment. Strategic alignment is the suitability between the expected external environmental conditions and the internal capabilities of the company. SRP was developed from three dimensions, namely the internal conditions of the company, the external conditions of the company, and the dimensions of time-oriented in the past, present, and future time. 
The strategic reference point was developed using three dimensions namely the company's internal reference point, the company s external reference point and time as the company's reference point. In the context of the capital market, in general, the company includes several quarterly earnings figures in the previous period in the earnings announcement for the current period as a benchmark. Benchmarks presented affect the magnitude of changes in earnings that are discussed and evaluated by managers in earnings announcements (Shoham \& Fiegenbaum, 2002).

The reporting strategy used by managers depends on the manager's goals. Two general disclosure objectives are to maximize (minimize) increase (decrease) in earnings by lowering the benchmark of the previous period's earnings and smoothing changes in erarnings by providing benchmarks closest to current earnings (Schrand \& Walther, 2000). Libby et al. (2006) discuss a benchmark model where actual earnings is assessed relative to benchmarks related to each form of management guidance. Investors make estimates based on guidance (Han \& Tan, 2007).

Multiple benchmarks is an information disclosure strategy in company earnings announcements that considers more than one benchmark. This strategy is the development of the concept of multiple reference points or strategic reference points (Fiegenbaum et al., 1996) which explain that there are three dimensions of reference points namely internal, external and time. Time as a reference point is divided into two periods, namely past and future.

In the context of accounting and financial research, multiple benchmark information forms can be used as one form of earnings announcements. The multiple benchmark strategy of earnings announcements is said to be better because the information presented is comprehensive information, namely information on previous earnings, current earnings, and future information in the form of management guidance. The management guide is the management's explanation regarding estimation performance in the form of the company's internal and external activities. Internal activities can be in the form of product and service issues, as well as organizational issues, while external activities such as economic conditions and government regulations (Wahyuni et al., 2016).

\subsection{Heuristic}

Heuristics are defined as a rule of thumb, which is a practical and simple action taken by individuals in making decisions in conditions of high uncertainty. Individuals do not think using mathematical analysis and tend to be pragmatic. Heuristics are cognitive "shortcuts" that can cause bias and contribute to mistakes (Habbe, 2017) and the consequence this has on earnings estimation and stock valuation. In particular, the over/under reaction creates an over response to the earnings information that is persistent in the long-term and an under reaction to the earnings information that changes extremely in the short-term. This research was designed with a $2 \times 2 \times 4$, full factorial. Data was analyzed by repeated measures ANOVA within-subject. Twenty post-graduate Master students were participants in the experimental. The experimental revealed that investors relied heavily on previous earnings and made the level and pattern of the previous earnings their initial belief (anchor). Heuristics is a cognitive technique that acts as a shortcut to facilitate problem-solving and simplify decision making in situations of uncertainty. Although heuristics can increase the ease and efficiency of decisions, they can also cause bias and produce errors (Richie \& Josephson, 2017) limiting future study of educational interventions designed to improve calibration of medical decisions. This study presents validity data to support a vignette-based instrument quantifying bias due to the anchoring, availability, and representativeness heuristics. APPROACH Participants completed questionnaires requiring assignment of probabilities to potential outcomes of medical and nonmedical scenarios. The instrument randomly presented scenarios in one of two versions: Version A, encouraging heuristic bias, and Version $\mathrm{B}$, worded neutrally. The primary outcome was the difference in probability judgments for Version A versus Version B scenario options. RESULTS Of 167 participants recruited, 139 enrolled. Participants assigned significantly higher mean probability values to Version A scenario options $(\mathrm{M}=9.56, \mathrm{SD}=3.75)$.

Heuristic factors will influence individuals when making a decision in conditions of high uncertainty. There are two heuristic factors described in this research, namely representativeness and anchoring-adjustment.

\subsubsection{Representativeness}

Heuristic representativeness is one of the heuristic principles that are important in influencing financial decisions (Habbe, 2017) and the consequence this has on earnings estimation and stock valuation. In particular, the over/ under reaction creates an over response to the earnings information that is persistent in the long-term and an under reaction to the earnings information that changes extremely in the short-term. This research was designed with a $2 \times 2 \times 4$, full factorial. Data was analyzed by repeated measures ANOVA within-subject. Twenty post-graduate Master students were participants in the experimental. The experimental revealed that investors relied heavily on previous earnings and made the level and pattern of the previous earnings their initial belief (anchor). Heuristic representativeness is a psychological bias that explains that in conditions of uncertainty, an investor tends to believe in history in terms of the common results of a company's performance in general (Boussaidi, 2013).

Heuristic representativeness can bias decisions if they depend on information patterns. For example, the bias that occurs in a doctor's diagnosis of a patient's disease is influenced by pattern recognition which causes the doctor not to give enough appreciation so that the diagnosis tends to be similar (Richie \& Josephson, 2017) limiting future study of educational interventions designed 
to improve calibration of medical decisions. This study presents validity data to support a vignette-based instrument quantifying bias due to the anchoring, availability, and representativeness heuristics. APPROACH Participants completed questionnaires requiring assignment of probabilities to potential outcomes of medical and nonmedical scenarios. The instrument randomly presented scenarios in one of two versions: Version A, encouraging heuristic bias, and Version B, worded neutrally. The primary outcome was the difference in probability judgments for Version A versus Version B scenario options. RESULTS Of 167 participants recruited, 139 enrolled. Participants assigned significantly higher mean probability values to Version A scenario options $(M=9.56$, $\mathrm{SD}=3.75)$. In the capital market, investors generally buy stocks after prices rise and expect this increase to continue. Conversely, investors tend to ignore stocks when the price is below its intrinsic value. Investors who use the heuristic representativeness in making investment decisions believe that they can see patterns that are actually random processes (Laih, 2016).

A consistently positive earning pattern will represent a positive future performance so that investors will overestimate future earnings. Conversely, a consistently negative earning pattern will represent negative future performance as well so that investors will underestimate future earnings (Habbe, 2017) and the consequence this has on earnings estimation and stock valuation. In particular, the over/ under reaction creates an over response to the earnings information that is persistent in the long-term and an under reaction to the earnings information that changes extremely in the short-term. This research was designed with a $2 \times 2 \times 4$, full factorial. Data was analyzed by repeated measures ANOVA within-subject. Twenty post-graduate Master students were participants in the experimental. The experimental revealed that investors relied heavily on previous earnings and made the level and pattern of the previous earnings their initial belief (anchor). Heuristic representativeness implies that a value is based on the level of representation which results in bias in making estimates. Heuristic representativeness explains that investors will depend on earning patterns. Thus, investors tend to overestimate earnings patterns that are consistently positive. Conversely, investors tend to underestimate the company's future earnings on earning patterns that are consistently negative. Based on these explanations, the hypothesis is formulated as follows.

H1: Investors will overestimate future earnings if they obtain information on previous earnings, current earnings and management guidance are positive.

H2: Investors will underestimate future earnings if they obtain information on previous earnings, current earning and management guidance is negative.

\subsubsection{Anchoring-adjustment}

The anchoring-adjustment model explains that in many situations, individuals make estimates by departing from the initial value (anchor) which then makes adjustments to the results of the final answer. The initial value can be based on past period earnings (Wahyuni et al., 2016). Anchoring-adjustment Heuristic describes a phenomenon where information greatly influences decisions, especially information found at the beginning of a particular situation (Richie \& Josephson, 2017) limiting future study of educational interventions designed to improve calibration of medical decisions. This study presents validity data to support a vignette-based instrument quantifying bias due to the anchoring, availability, and representativeness heuristics. APPROACH Participants completed questionnaires requiring assignment of probabilities to potential outcomes of medical and nonmedical scenarios. The instrument randomly presented scenarios in one of two versions: Version A, encouraging heuristic bias, and Version $\mathrm{B}$, worded neutrally. The primary outcome was the difference in probability judgments for Version A versus Version B scenario options. RESULTS Of 167 participants recruited, 139 enrolled. Participants assigned significantly higher mean probability values to Version A scenario options $(\mathrm{M}=9.56, \mathrm{SD}=3.75)$.

Adjustments (adjustments) are usually inadequate because they end after reaching an acceptable value for an estimate. This inadequate adjustment is only possible if the anchor value is outside the acceptable distribution of values. This might occur because of extreme or incorrect anchor values (Bahník et al., 2017). However, the anchoring effect does not always occur due to inadequate adjustments. (Gilovich \& Epley, 2006) who looked at the anchoring paradigm found that anchoring effects occur due to an increase in the accessibility of information that is consistent with the anchor, not an inadequate adjustment.

The anchoring effect is usually explained in terms of selective accessibility of information that is consistent with the anchor value, where the respondent tests whether the anchor might be the correct answer. This is a bias that occurs due to the temporary suspicion of information that is considered the most supportive (Frederick \& Mochon, 2011).

Belief adjustment theory explains that high (low) anchors will decrease (increase) when faced with negative (positive) information when compared to low anchors (high) (Hartono, 2004; Habbe \& Mande, 2016). Investors tend to overestimate the positive (negative) initial earnings information. Investors will estimate earnings more positively (more favorable) if they consider positive past information, and vice versa (Wahyuni et al., 2016).

H3: Investors will overestimate future earnings if they obtain information on positive previous earnings but current earnings and management guidance are negative.

H4: Investors will underestimate future earnings if they obtain information on negative previous earnings but current earnings and management guidance are positive. 


\section{Experimental design}

\subsection{Experimental design}

This research is an experimental laboratory with $2 \times 2$ full factorial between subject. The level of previous earning ( $t-1$ and $t-2)$ is positive and negative. Current earning level (t0) and management guidance are positive and negative. The experimental laboratory is an experimental method that is held in a controlled order that facilitates the measurement process (Nahartyo \& Utami, 2016).

Table 1. Experimental design $2 \times 2$ full factorial (source: research design, 2019)

\begin{tabular}{|c|l|l|l|}
\hline \multirow{2}{*}{ Variable } & \multicolumn{2}{c|}{$\begin{array}{c}\text { Current Earning and Management } \\
\text { Guidance }\end{array}$} \\
\cline { 2 - 4 } \multicolumn{2}{|c|}{} & \multicolumn{1}{|c|}{ Positive } & \multicolumn{1}{c|}{ Negative } \\
\hline \multirow{2}{*}{$\begin{array}{l}\text { Previous } \\
\text { Earning }\end{array}$} & $\begin{array}{l}\text { Overestimate of } \\
\text { tive } \\
\text { (representativeness) }\end{array}$ & $\begin{array}{l}\text { Overestimate of } \\
\text { target earning } \\
\text { (anchoring- } \\
\text { adjustment) }\end{array}$ \\
\cline { 2 - 4 } & $\begin{array}{l}\text { Nega- } \\
\text { tive }\end{array}$ & $\begin{array}{l}\text { Underestimate of } \\
\text { target earning } \\
\text { (anchoring- } \\
\text { adjustment) }\end{array}$ & $\begin{array}{l}\text { Underestimate of } \\
\text { target earning } \\
\text { (representativeness) }\end{array}$ \\
\hline
\end{tabular}

Experimental design (Table 1) shows that the previous earnings are past period earnings ( $\mathrm{t}-1$ and $\mathrm{t}-2)$ which are assumed to be positive when increasing earnings and are considered negative when decreasing earnings. Current earnings are the current period earnings (t0) which are also assumed to be the same as the previous earnings which are positive when there is an increase in earnings and is considered negative when decreasing earnings. While management guidelines are management information (internal and external) that has a pattern that is under the current earnings value.

Respondents in this research used 80 students of economics doctoral program and accounting master at Hasanuddin University. Selection of students as proxies from investors because students are individuals who have knowledge but lack experience. Students are considered to have an understanding of investment theory but do not have much experience in becoming a real investor. This helps researchers to control the possible validity problems. Hypothesis testing is done by using a two-way analysis of variance (ANOVA).

\subsection{Variable measurement}

\subsubsection{Dependent variable}

The dependent variable used in this research is the estimation of future earnings $(t+1)$ made by investors based on current earnings information with management guidance $(\mathrm{t} 0)$ and previous earnings information $(\mathrm{t}-1$ and $t-2$ ). The measurement of estimation uses the amount of earning predicted by the subject which is divided into two categories, namely high (over) and low (under). A high category if the estimated future earning is greater than the target earning which in this case is considered that investors predict the company will get a high earning in the future (overestimate). Conversely, a low category if the estimated future earnings are smaller than the target earning assumed that investors consider the company to get a low earning in the future (underestimate).

Target earning is an actual value called intrinsic value. There are two ways to determine the intrinsic value of shares, namely the technical and fundamental approaches. Technical approaches can use market data such as price and volume of shares, while the fundamental approach uses corporate fundamental data such as earnings, dividends, sales and so forth (Hartono, 2017). Target earning is obtained from linear regression using the Maximum Likelihood Estimation (MLE) method (Bernard \& Thomas 1990; Bloomfield et al., 2003; Habbe, 2017) and the consequence this has on earnings estimation and stock valuation. In particular, the over/under reaction creates an over response to the earnings information that is persistent in the long-term and an under reaction to the earnings information that changes extremely in the short-term. This research was designed with a $2 \times 2 \times 4$, full factorial. Data was analyzed by repeated measures ANOVA within-subject. Twenty post-graduate Master students were participants in the experimental. The experimental revealed that investors relied heavily on previous earnings and made the level and pattern of the previous earnings their initial belief (anchor. The regression equation is as follows.

$$
\begin{aligned}
& \text { Earning }_{t+1}=a+b_{1} \text { Earning }_{t 0}+ \\
& b_{2} \text { Earning }_{t-1}+b_{3} \text { Earning }_{t-2} .
\end{aligned}
$$

The value of earnings $t+1$ is the estimated value of future earnings predicted based on the value of current and previous earnings. the value of is the constant of earnings $t+1$ while is the coefficient of current earnings and past earnings. Constant values and coefficients are obtained from the regression of current earnings $(t)$ and past earnings $(t-1, t-2, t-3)$.

$$
\begin{aligned}
& \text { Earning }_{t}=\alpha+\beta_{1} \text { Earning }_{t-1}+ \\
& \beta_{2} \text { Earning }_{t-2}+\beta_{3} \text { Earning }_{t-3}+\varepsilon
\end{aligned}
$$

The value of earnings $t$ is the current earnings while the earnings of $t-1, t-2, t-3$ are the value of previous earnings. The value of $\alpha$ shows the constant of the current earnings value while $\beta$ is the coefficient of the previous earnings.

The data used is data on corporate earnings in the food and beverage subsector listed on the Indonesia Stock Exchange from 2014-2017. Companies that do not get earnings or suffer losses for 2 consecutive years are excluded from the sample.

\subsubsection{Independent variable}

The independent variable used is the previous earning $(\mathrm{PE})$ then uses two years ago earning series $(t-1$ and $t-2)$. Current earnings (CE) information along with 
future information in the form of management guidance $(\mathrm{MG})$ are also independent variables in this research. Current earning with management guidance $(t 0)$ is divided into two groups, positive and negative.

Management guidance in this research is a form of multiple benchmark information, namely information disclosure strategies in earnings announcements made by companies based on more than one reference, namely previous earnings information, current earnings information and future information (Wahyuni \& Hartono, 2012) which, in turn, influences investor's judgments (Schrand \& Walther, 2000; Krische, 2005; Wahyuni et al., 2016). Thus, the information presented is in the form of current earnings information, description and management guidance that contains internal information (in the form of product and service issues, and organizational issues) and external (in the form of economic conditions and government regulations) companies.

\subsection{Experimental procedure}

Experiments were carried out with laboratory designs conducted in classrooms at the postgraduate campus building at the faculty of economics and business at Hasanuddin University. Treatment is carried out twice, one time for a doctoral program and once for a accounting master's program. The first stage, random subjects will be divided into four groups. Randomization aims to control pollutant variables (Sekaran \& Bougie, 2013). Next, the subject was asked to fill out a demographic questionnaire containing gender, age, and education. The next stage, the subjects were asked to predict the company's future earnings without doing mathematical calculations. In the last stage, subjects were asked to fill out a binary questionnaire for manipulation checks.

\subsection{Treatment}

The case material and instruments used in this research are the development of instruments that were previously used by Krische (2005) in the form of information disclosure with multiple benchmark strategies. The development was carried out by dividing the types of instruments which were previously divided into two, developed into four types of instruments according to the number of treatment groups.

Research instruments in the form of electronic forms using links from google form. Instruments in the form of financial statements of companies that have earnings after $\operatorname{tax}$ (EAT) that have a pattern according to the treatment group. The fundamental information used is the financial statements of PT Mayora Indah, Tbk. and PT Campina Ice Cream Industry, Tbk. for representativeness group. The Financial statement of PT Indofood CBP Sukses Makmur, Tbk and PT Siantar Top, Tbk. for the anchoring-adjustment group.

\subsection{Manipulation check}

Manipulation checks are carried out to measure the effectiveness of experimental treatments and ensure subjects understand the tasks given (Habbe, 2017) and the consequence this has on earnings estimation and stock valuation. In particular, the over/under reaction creates an over response to the earnings information that is persistent in the long-term and an under reaction to the earnings information that changes extremely in the short-term. This research was designed with a $2 \times 2 \times 4$, full factorial. Data was analyzed by repeated measures ANOVA within-subject. Twenty post-graduate Master students were participants in the experimental. The experimental revealed that investors relied heavily on previous earnings and made the level and pattern of the previous earnings their initial belief (anchor. Manipulation means that we create various levels of the independent variable to assess the impact on the dependent variable (Sekaran \& Bougie, 2013). Manipulation checks are performed on the experimental subject (investor) by giving five questions in the form of a binary questionnaire (true or false). investors who provide improper answers are stated not to pass manipulation checks, so they must be eliminated from the list of respondents.

\section{Result and discussions}

\subsection{Subject demography}

The participants in this experiment were 82 students of economics doctoral programs and accounting masters at Hasanuddin University. But there were 2 students who were declared not eligible to be participants based on the results of manipulation testing. Thus, there were only 80 participants left consisting of 39 doctoral program students in economics and 41 people from the accounting master program who were the subjects of this experiment (Table 2). 80 participants consisted of 33 men and 47 women ranging in age from 23 to 45 years.

Table. 2 Subject demography (source: SPSS output result, 2019)

\begin{tabular}{|l|l|c|c|c|c|}
\hline & & Freq & Min & Max & $\%$ \\
\hline \multirow{2}{*}{ Gender } & Male & 33 & & & 41.25 \\
\cline { 2 - 6 } & Female & 47 & & & 58.75 \\
\hline \multirow{2}{*}{ Age } & & & 23 & 45 & \\
\hline \multirow{2}{*}{ Education } & Doctoral & 39 & & & 51.25 \\
\cline { 2 - 6 } & Master & 41 & & & 48.75 \\
\hline
\end{tabular}

\subsection{Hypothesis test and discussion}

\subsubsection{Interaction of previous earning, current earning and management guidance}

Table 3 describes the Interaction of previous earning, current earning, and management guidance. Previous earnings as the first independent variable have a highly significant level where the value of $\mathrm{F}=794.07, \mathrm{P}=0.000$. The same is shown in the variable Current Earning and 
Table 3. ANOVA between subject factorial $2 \times 2$ (source: SPSS output result 2019)

\begin{tabular}{|l|c|c|c|c|c|}
\hline \multicolumn{1}{|c|}{ Factors } & Sum of Square & df & Mean Square & F & P Value \\
\hline PE & 80650717.88 & 1 & 80650717.88 & 794.07 & 0.000 \\
\hline CEMG & 82266428.75 & 1 & 82266428.75 & 809.98 & 0.000 \\
\hline PE $\times$ CEMG & 177681613.63 & 1 & 177681613.63 & 1749.42 & 0.000 \\
\hline
\end{tabular}

Management Guidance with a value of $\mathrm{F}=809.98, \mathrm{P}=$ 0.000 . These results indicate that the estimation is different from the level of each independent variable. In other words, the independent variables had different effects on Earning Estimation. The interaction between previous earnings and current earnings and management guidance shows significant results with a value of $\mathrm{F}=1.749 .42, \mathrm{P}=$ 0.000 . These results indicate that the effect between Previous Earning and Current Earning Management Guidance on Earning Estimates differs between levels of earnings.

\subsubsection{Representativeness heuristic}

Heuristic testing of representation was carried out in groups of investors who received positive (group I) Previous Earning (PE), Current Earning (CE) and Management Guidance (MG) information and negative (group II) positive Previous Earning (PE), Current Earning (CE) and Management Guidance (MG). The estimated target value calculated using the Maximum Likelihood Estimate (MLE) method shows that in the positive representativeness group, the revenue target is 111.76 while the representativeness group is negative, target earning is 87.06 , as shown in Table 4.

Experimental results were estimated at $112.72>$ earning targets 111.76, which investors overstated the earning information provided. Thus the first hypothesis is acceptable. The bias that occurs causes an estimation error of 0.95 . The experimental results in the negative information are also expected to come in at $92.70>87.06$. This result means that the second hypothesis is not acceptable.

These results indicate that investors react to positive information and do not react to negative information. The results of this test also provide evidence that investors do not always show excessive reactions to information that is constant or relatively the same. The investor considers the previous information does not always reflect the same value for future values. This also means that in estimating earnings, investors do not always experience the heuristic representativeness. This result is different from the previous research conducted by Habbe (2017) and the consequence this has on earnings estimation and stock valuation. In particular, the over/under reaction creates an over response to the earnings information that is persistent in the long-term and an under reaction to the earnings information that changes extremely in the short-term. This research was designed with a $2 \times 2 \times 4$, full factorial. Data was analyzed by repeated measures ANOVA within-subject. Twenty post-graduate Master students were participants in the experimental. The experimental revealed that investors relied heavily on previous earnings and made the level and pattern of the previous earnings their initial belief (anchor and Bloomfield et al. (2003) which shows that investors experience the heuristic representativeness in making estimated earnings.

\subsubsection{Anchoring-adjustment Heuristic}

Based on the test results in Table 5, it can be explained that the anchoring-adjustment heuristics occurred. Heuristic anchoring-adjusment testing was carried out in group III (investors who received positive Previous Earning, negative Current Earning dan Management Guidance) and group IV (investors who received negative Previous Earning, positive Current Earning and Management Guidance). The earning target of the calculation using the Maximum Likelihood Eestimation method obtained a value of 1,215.20 for target group III earnings and 4.571.49 for group IV.

The results of hypothesis testing in group III indicate that investors underestimate future earnings when they obtain positive Previous Earning and negative Current Earning, Management Guidance information. This is shown in the table that the estimated investor earnings amounted to $1,065.20<1,215.20$ target earnings. The error rate is shown to be 150.00 . The test results in group IV show that investors overestimate the company's future earnings on positive Previous Earning and negative Current Earning, Management Guidance information. The estimated value is indicated at 5,101.45 > 4,571.49 target earnings. The prediction error rate is indicated at 529.96 . the results of this statistical test mean that hypotheses III and IV cannot be accepted.

Unacceptable both hypotheses indicate that investors overreaction to new information received. It is evident from the results of the estimation of future earnings made by investors, where investors do not depend on the initial value (anchor) but are affected by new information.

Table 4. Test of Representativeness heuristic (source: SPSS output result 2019)

\begin{tabular}{|c|l|c|c|c|c|c|}
\hline Group & \multicolumn{1}{|c|}{ Earning Pattern } & N & Earning Estimated & Earning Target & Estimated & Estimation Error \\
\hline I & PE (+) CE MG (+) & 20 & 112.72 & 111.76 & Overestimate & 0.95 \\
\hline II & PE (-) CE MG (-) & 20 & 92.70 & 87.06 & Overestimate & 5.64 \\
\hline
\end{tabular}


Table 5. Test of Anchoring-adjustment Heuristic (source: SPSS output result, 2019)

\begin{tabular}{|c|c|c|c|c|c|c|}
\hline Group & Earning Pattern & N & Earning Estimated & Earning Target & Estimated & Estimation Error \\
\hline III & PE (+) CE MG (-) & 20 & 1065.20 & 1215.20 & Underestimate & $(150.00)$ \\
\hline IV & PE (-) CE MG (+) & 20 & 5101.45 & 4571.49 & Overestimate & 529.96 \\
\hline
\end{tabular}

This condition shows that there is no anchor bias in the company's future earning forecasting. Unlike the previous research conducted by Bloomfield et al. (2003), Habbe (2017)and the consequence this has on earnings estimation and stock valuation. In particular, the over/ under reaction creates an over response to the earnings information that is persistent in the long-term and an under reaction to the earnings information that changes extremely in the short-term. This research was designed with a $2 \times 2 \times 4$, full factorial. Data was analyzed by repeated measures ANOVA within-subject. Twenty post-graduate Master students were participants in the experimental. The experimental revealed that investors relied heavily on previous earnings and made the level and pattern of the previous earnings their initial belief (anchor and Wahyuni et al. (2016) which shows the existence of anchoring effects in earnings forecasting by investors. This experiment shows the opposite results, there is a recency effect in the earning forecasting process carried out by investors. This result also shows the role of the form of information disclosed. A more comprehensive form of multiple benchmark information helps investors predict the company's future earnings value more precisely so that it can reduce the anchoring bias that occurs.

\section{Conclusions, implications and limitations}

Earning forecasting is important for investors to predict the company's performance in the future. Errors in forecasting company earnings will have an impact on investor errors predicting the company's future stock price, causing investors to make investment decisions wrongly. Decision making by investors is generally influenced by two things, namely the fundamental factors of the company and the psychological factors of the investor itself.

Many of the previous studies show that investors are more influenced by psychological factors in making investment decisions. Investors act heuristically in forecasting company performance in the future. Two of them are heuristic representativeness and anchoring-adjustment. Heuristic representativeness describes the behavior of investors making decisions based on the similarity of values in the previous information. While the heuristic anchoring adjustment explains the behavior of investors who are influenced by the anchor, then make adjustments to the new information obtained. It is this heuristic which makes the investor's decision biased.

This research provides results that are not in line with some previous studies. This research shows that investor decisions do not always become biases caused by psychological heuristic factors experienced. Fundamental factors become one of the considerations of investors in making investment decisions. A comprehensive form of information disclosure can be one solution to reduce the possibility of a decision bias. Evidenced by the form of multiple benchmark information disclosure, investors are able to reduce the influence of heuristic psychology that is commonly experienced by most investors.

The results of this research also provide an indication of the recency effect that occurs in investor decision making so that further researchers can consider conducting an analysis of the effect of a review that affects investors. Further researchers can also use different experimental designs.

\section{Refferences}

Bahník, Š., Englich, B., \& Strack, F. (2017). Anchoring effect. In F. Pohl Rudiger (Ed.), Cognitive illusions: intriguing phenomena in judgement, thinking and memory (2nd Ed.) (pp. 223-241). Routledge.

Bernard, V. L., \& Thomas, J. K. (1990). Evidence that stock prices do not fully reflect the implications of current earnings for future earnings. Journal of Accounting and Economics, 13(4), 305-340. https://doi.org/10.1016/0165-4101(90)90008-R

Bloomfield, R., Libby, R., \& Nelson, M. W. (2003). Do investors overrely on old elements of the earnings time series? Contemporary Accounting Research, 20(1), 1-31. https://doi.org/10.1506/N8T8-9QR7-YUCX-91X2

Bodie, Z., Kane, A., \& Marcus, A. J. (2009). Essentials of investments (8th ed.). McGraw-Hill Companies, Incorporated.

Boussaidi, R. (2013). Representativeness heuristic, investor sentiment and overreaction to accounting earnings: the case of the Tunisian stock market. Procedia - Social and Behavioral Sciences, 81(1974), 9-21.

https://doi.org/10.1016/j.sbspro.2013.06.380

De Bondt, W. F. M., \& Thaler, R. H. (1987). Further evidence on investor overreaction and stock market seasonality. The Journal of Finance, 42(3), 557-581. https://doi.org/10.1111/j.1540-6261.1987.tb04569.x

Fama, E. F. (1970). Efficient capital markets: a review of theory and empirical work. American Economic Review, 25(2), 383417. https://doi.org/10.1111/j.1540-6261.1970.tb00518.x

Fiegenbaum, A., Hart, S., \& Schendel, D. (1996). Strategic reference point theory. Strategic Management Journal, 17(3), 219-235. https://doi.org/10.1002/(SICI)10970266(199603)17:3<219::AID-SMJ806>3.3.CO;2-E

Frederick, S. W., \& Mochon, D. (2011). A scale distortion theory of anchoring. Journal of Experimental Psychology: General, 141(1), 124-133. https://doi.org/10.1037/a0024006

Gilovich, T., \& Epley, N. (2006). The anchoring-and-adjustment heuristic. Why the adjustments are insufficient. Psychological Science, 17(4), 311-318.

https://doi.org/10.1111/j.1467-9280.2006.01704.x

Habbe, A. H. (2017). Estimation error of earnings information: a test of representativeness and anchoring-adjustment heu- 
ristic. International Journal of Economics and Financial Issues, 7(1), 224-233.

Habbe, A. H., \& Mande, H. (2016). The effect of information sequential and personality on the investor belief revision (an experimental study in decision making). PONTE International Scientific Researchs Journal, 72(10), 150-166. https://doi.org/10.21506/j.ponte.2016.10.13

Han, J., \& Tan, H. T. (2007). Investors' reactions to management guidance forms: The influence of multiple benchmarks. Accounting Review, 82(2), 521-543.

https://doi.org/10.2308/accr.2007.82.2.521

Hartono, J. (2004). How, why and when investors revise their beliefs to company information and their implications to firm's announcement policy. ANDI.

Hartono, J. (2017). Teori Portofolio Dan Analisis Investasi (11th ed.). BPFE.

Helson, H. (1964). Adaptation-level theory: an experimental and systematic approach to behavior. Harper \& Row.

Jame, R., Johnston, R., Markov, S., \& Wolfe, M. C. (2016). The value of crowdsourced earnings forecasts. Journal of Accounting Research, 54(4), 1077-1110. https://doi.org/10.1111/1475-679X.12121

Kahneman, D., \& Tversky, A. (1979). Prospect theory: an analysis of decision under risk. Econometrica, 47(2), 263-292. https://doi.org/10.2307/1914185

Konstantinidi, T., \& Pope, P. F. (2016). Forecasting risk in earnings. Contemporary Accounting Research, 33(2), 487-525. https://doi.org/10.1111/1911-3846.12158

Krische, S. D. (2005). Investors' evaluations of strategic in earnings announcements. The Accounting Review, 80(1), 243-268. https://doi.org/10.2308/accr.2005.80.1.243

Laih, Y.-W. (2016). Do experts in financial magazines exhibit the representativeness heuristic? Evidence from Taiwan. Accounting and Finance Research, 5(4), 49-62. https://doi.org/10.5430/afr.v5n4p49

Lee, Y. H., Dunbar, N. E., Miller, C. H., Lane, B. L., Jensen, M. L., Bessarabova, E., Burgoon, J. K., Adame, B. J., Valacich, J. J., Adame, E. A., Bostwick, E., Piercy, C. W., Elizondo, J., \& Wilson, S. N. (2016). Training anchoring and representativeness bias mitigation through a digital game. Simulation and Gaming, 47(6), 751-779. https://doi.org/10.1177/1046878116662955

Libby, R., Tan, H. T., \& Hunton, J. E. (2006). Does the form of management's earnings guidance affect analysts' earnings forecasts? Accounting Review, 81(1), 207-225. https://doi.org/10.2308/accr.2006.81.1.207

Lim, T. (2001). Rationality and analysts' forecast bias. Journal of Finance, 56(1), 369-385. https://doi.org/10.1111/0022-1082.00329

Lo, A. W. (1989). The adaptive markets hypothesis: market efficiency from an evolutionary perspective. Journal of Cellular Physiology, 139(2), 313-319. https://doi.org/10.1002/jcp.1041390213

Monahan, S. J. (2017). Financial statement analysis and earnings forecasting. Foundations and Trends in Accounting, 12(2), 105-215. https://doi.org/10.1561/1400000036
Nahartyo, E., \& Utami, I. (2016). Panduan Praktis Riset Eksperimen. INDEKS.

Pompian, M. M. (2012). Behavioral finance and investor types: managing behavior to make better investment decisions. Wiley. https://doi.org/10.1002/9781119202417

Praditha, R., Haliah, H., Habbe, A. H., Rura, Y., \& Anwar, A. I. (2020). Accounting information disclosure: single versus multiple benchmark. Hasanuddin Economics and Business Review, 4(1), 22-28. https://doi.org/10.26487/hebr.v4i1.2352

Richie, M., \& Josephson, S. A. (2017). Quantifying heuristic bias: anchoring, availability, and representativeness. Teaching and Learning in Medicine, 30(1), 67-75. https://doi.org/10.1080/10401334.2017.1332631

Schrand, C. M., \& Walther, B. R. (2000). Strategic benchmarks in earnings announcements: the selective disclosure of priorperiod earnings components we have received helpful comments from Ray Ball. The Accounting Review, 75(2), 151-177. https://doi.org/10.2308/accr.2000.75.2.151.

Sekaran, U., \& Bougie, R. (2013). Research methods for business: a skill-building approach. Wiley.

Shoham, A., \& Fiegenbaum, A. (2002). Competitive determinants of organizational risk-taking attitude: the role of strategic reference points. Management Decision, 40(2), 127-141. https://doi.org/10.1108/00251740210422802

Siddiqi, H. (2015). Anchoring adjusted capital asset pricing model. Risk and Sustainable Management Group Working Paper Series. The University of Queensland. https://doi.org/10.2139/ssrn.2686990

Thibaut, J. W., \& Kelley, H. H. (2017). The social psychology of groups. Routledge. https://doi.org/10.4324/9781315135007

Tversky, A. (1992). Advances in Prospect theory: cumulative representation of uncertainty. Journal of Risk and Uncertainty, 5, 297-323. https://doi.org/10.1007/BF00122574

Tversky, A., \& Kahneman, D. (1973). Judgements under uncertainty: Heuristics and biases. Oregon Research Institute Research Bulletin, 13(1), 201-210. https://doi.org/10.1016/0732-118X(84)90024-2

Wahyuni, S., \& Hartono, J. (2012). Reminder effect and anchoring-adjustment in earnings announcements: implementation of prior-period benchmark disclosure strategy. Journal of Indonesian Economy and Business, 27(3), 390-405.

Wahyuni, S., Hartono, J., \& Nahartyo, E. (2016). Implementasi Strategi Pengungkapan Informasi Laba Patok Duga Tunggal dan Multipel dalam Rerangka Teori Titik Acuan Ganda. Simposium Nasional Akuntansi XIX, 1-30.

Ying Luo, G. (2013). Can representativeness heuristic traders survive in a competitive securities market? Journal of Financial Markets, 16(1), 152-164.

https://doi.org/10.1016/j.finmar.2012.05.001 